\title{
EUFEMISME DAN DISFEMISME DALAM RUBRIK BERITA "KRIMINAL" SURAT KABAR HARIAN MUSI BANYUASIN
}

\author{
Noepri Dikawati \\ email: nopridikawati90@gmail.com \\ SMP Negeri 6 Unggul Sekayu
}

\begin{abstract}
ABSTRAK - Tujuan penelitian ini untuk mendeskripsikan eufemisme dan disfemisme dalam surat kabar Harian Musi Banyuasin dalam rubrik berita "Kriminal". Teknik pengumpulan data yang digunakan adalah teknik dokumentasi. Selanjutnya untuk menganalis data digunakan teknik ganti dan teknik perluas.Berdasarkan hasil analisis dan pembahasan dalam penelitian analisis distribusi eufemisme dan disfemisme yang memiliki persamaan dengan bentuk yang digantikannya. Unsur metafora dapat menjadi penentu dalam distribusi disfemisme, karena dapat berpengaruh pada cakupan makna. Berdasarkan analisis kolokasi ditemukan kecenderungan pemakaian eufemisme dan disfemisme yang disebabkan oleh pergeseran kolokasi. Sedangkan makna emotif yang terdapat di dalam analisis eufemisme dan disfemisme adalah makna menguatkan.Berdasarkan analisis distribusi, kolokasi, dan makna emotif dapat dikatakan tidak ada eufemisme dan disfemisme yang bersinonim secara absolut dan sempurna dengan bentuk kebahasaan yang digantikannya. Hal ini dipengaruhi oleh perbedaan distribusi, cakupan makna, pergeseran kolokasi dan makna emotif.
\end{abstract}

Kata Kunci: Eufemisme, Disfemisme, dan Surat kabar.

\begin{abstract}
The purpose of this research is to describe the euphemisms and dysfemisms in the daily newspaper Musi Banyuasin in the news rubric "Criminal". The data collection technique used is documentation technique. Furthermore, to analyze the data, use of replacement techniques and expansion techniques. Based on the results of the analysis and discussion in the analysis of the distribution of euphemisms and dysphemisms, which have similarities to the forms they replace. Metaphor elements can be decisive in the distribution of dysfemism, because they can affect the scope of meaning. Based on the collocation analysis, it is found that the tendency to use euphemisms and dysphemisms is caused by a shift in collocation. Meanwhile, the meaning of emotive contained in the analysis of euphemisms and dysphemism is the meaning of strengthening. Based on the analysis of distribution, collocation, and emotive meaning, it can be said that there are no euphemisms and dysfemisms that are synonymous absolutely and perfectly with the linguistic forms they replace. This is influenced by differences in distribution, scope of meaning, shift in collocation and emotive meaning.
\end{abstract}

Keywords: euphemisms, dysphemisms, newspaper

PENDAHULUAN

Perubahan yang terjadi dalam
bahasa mencakup penambahan,
pengurangan, maupun pergeseran.
Penambahan dan pengurangan yang

Perubahan yang terjadi dalam terjadi dalam bahasa tidak saja berhubungan dengan masalah kuantitas leksem, tetapi juga berhubungan dengan leksem.

Dalam hubungannya dengan kualitas leksem inilah perubahan leksem berambah 
pada aspek makna atau semantik.

Menurut Chaer (2007:310), perubahan makna kata disebabkan oleh beberapa faktor, yaitu perkembangan dalam bidang ilmu dan teknologi, perkembangan sosial budaya, perkembangan pemakaian kata, pertukaran tanggapan indra, dan adanya asosiasi. Hal itu yang menyatakan bahwa keberadaan makna dalam suatu bahasa tidak dapat dilepaskan dari kualitas pengalaman perkembangan ilmu pengetahuan, maupun tingkat sosial budaya masyarakat pemakainya. Jadi, dapat disimpulkan perubahan makna suatu kata sangat dipengaruhi oleh perkembangan ilmu pengetahuan dan kebudayaan masyarakat.

Eufemisme dan Disfemisme ini sering digunakan dalam Surat Kabar Harian Musi Banyuasin merupakan surat kabar harian yang terbit setiap hari, yang merupakan surat kabar umum yang memiliki pembaca paling banyak di Musi Banyuasin, menonjol sebagai harian politik dan memberikan dampak paling besar diantara publikasi harian untuk jangka panjang. Seperti media massa pada umumnya, Harian Musi Banyuasin menggunakan bahasa yang tidak selalu apa adanya. Selain bahasa yang diperindah, Harian Musi Banyuasin menggunakan bahasa yang diperkasar. Penyamaan orang atau manusia dengan benda merupakan hal yang tidak pantas. Gaya bahasa yang digunakan untuk memperhalus bahasa agar terkesan lebih indah bagi pembaca disebut eufemisme, sedangkan yang digunakan untuk memperkasar agar terkesan negatif bagi mitra tutur disebut disfemisme.

Chaer (2009:143) mengemukakan dalam pembicaraan mengenai perubahan makna yang meluas, menyempit, atau berubah secara total, kita berhadapan dengan sebuah kata atau sebuah bentuk yang tetap. Hanya konsep makna mengenai kata atau bentuk itu yang berubah.

Ullmann (2011:285)

mengemukakan eufemisme atau pseudoeufemisme adalah kekuatan yang memotivasi dibalik banyak perkembangan pejoratif. Jika penggantian kata dengan kata yang bersifat eufemisme itu tetap dirasakan demikian. Jika penggantian itu menjadi secara langsung dihubungkan dengan gagasan yang memang sengaja 
dirancang untuk ditutup-tutupi, maka akan mengakibatkan suatu "penurunan" makna secara tetap.

$$
\text { Sudaryanto }
$$

mengemukakan kata eufemisme berasal dari bahasa Yunani euphemizein yang bearti 'berbicara' dengan kata-kata yang jelas dan wajar'.

Haryanta (2012:68) mengemukakan eufemisme ungkapan yang lebih halus sebagai pengganti ungkapan yang dirasakan kasar, yang dianggap merugikan atau tidak menyenangkan.

Pengasaran atau disfemia adalah penggantian suatu ujaran yang bernuansa makna netral atau halus dengan ujaran lain yang mempunyai makna sama tapi dianggap mempunyai nilai rasa yang lebih kasar. Makna ujarannya tetap dipertahankan sama, hanya saja diungkapkan dengan kata yang bernilai rasa lebih halus yang berubah dari disfemia bukanlah makna kata atau makna ujaran, melainkan nilai rasa. Makna ujaran tetap dipertahankan. Gejala Disfemisme merupakan mengganti untuk kata-kata vulgar dan merupakan kebalikan dari eufemisme. Dari uraian di atas, dapat disimpulkan. Dengan kata lain, disfemisme merupakan suatu ungkapan dengan konotasi kasar, tidak sopan, atau menyakitkan hati mengenai sesuatu atau seseorang.

\section{Hakikat Berita}

Berita adalah padanan kata news dalam bahasa Inggris. Kata news itu sendiri menunjukkan adanya unsur waktu, apa yang new (apa yang baru). Berita berasal dari bahasa sansekerta "Vrit" yang dalam bahasa Inggris disebut "Write" yang mempunyai arti "ada" atau "terjadi". Vritta itu sendiri akhirnya dalam bahasa Indonesia menjadi "berita" atau "warta". Berita dalam kamus besar bahasa Indonesia didefinisikan sebagai laporan mengenai kejadian atau peristiwa yang masih hangat. Jadi artinya, berita dapat dikaitkan dengan kejadian atau peristiwa yang terjadi.

Menurut Chaer (2010:11), berita adalah kejadian yang diulang dengan menggunakan kata-kata. Seing juga ditambah dengan gambar, atau hanya berupa gambar-gambar saja. Dalam dunia jurnalistik, yang dimaksud berita adalah fakta atau informasi yang ditulis oleh wartawan dan disajikan dalam media pers, seperti surat kabar, majalah, radio, dan televisi. Tidak ada rumusan tunggal mengenai pengertian berita. English, Earl dan Clraence Hach mengatakan, "news is difficult to define, because it involves mani variable factors". Berita sulit didefinisikan karena mencakup banyak faktor variabel.

Berita sebagai laporan tercepat dari suatu peristiwa atau kejadian yang penting, faktual, dan menarik bagi para 
pembaca, serta menyakut kepentingan mereka. Berita merupakan laporan fakta atau ide dipilih oleh staf redaksi suatu harian yang mampu menarik perhatian khalayak umum. Hal ini disebabkan tidak seperti biasanya, pentingnya, dan mengandung segi-segi human interest. Wahyudi menjelaskan bahwa berita adalah laporan tentang suatu kejadian atau peristiwa yang memiliki nilai penting, menarik bagi khalayak umum, hangat, dan dipublikasikan secara halus melalui media massa periodik. Berita adalah informasi aktual tentang faktafakta dan opini yang menarik perhatian orang.

Berdasarkan beberapa pendapat di atas, dapat disimpulkan bahwa berita merupakan suatu laporan atau informasi fakta dan menarik perhatian bagi para pembaca. Informasi yang berkembang dimasyarakat diangkat menjadi berita disuatu media karena memiliki nilai berita yang tinggi dan layak untuk diekspose. Secara umum, wacana berita surat kabar terdiri dari berita ekonomi, politik, sosial budaya, pendidikan, hukum, dan kriminalitas, seni dan hiburan, serta olahraga. Jenis-jenis berita ini disajikan pada porsi yang berbedabeda sesuai dengan visi dan misi masingmasing surat kabar. Menurut penempatannya, berita-berita tersebut ada yang diletakkan pada halaman yang berbeda bergantung pada aktualitas dan nilai berita. Berita yang terletak pada halaman pertama dan bersambung pada halaman belakang pada surat kabar biasa disebut dengan headline (berita utama).

Dua jenis headline, yaitu teaser (penggoda) dan teller (pemberitahu). Headline teller yaitu berita utama yang berusaha menarik perhatian dengan mengungkapkan berita penting dengan jelas dan tepat secara ringkas. Isi headline teller biasanya langsung ke sasaran. Jenis kedua yaitu headline teaser yang menimbulkan perhatian dengan cara meningkatkan rasa ingin tahu atau dengan menghibur pembaca.

Media Massa (Mass Media) sering disingkat jadi "media" adalah channel, media (medium), saluran, sarana, atau alat yang digunakan dalam proses komunikasi massa,

yakni komunikasi yang diarahkan kepada orang banyak (channel of mass communication). Komunikasi massa sendiri merupakan kependekan dari komunikasi melalui media massa (communicate with media). Secara bahasa, menurut Kamus Besar Bahasa Indonesia

media adalah alat; sarana komunikasi se perti koran, majalah, $\underline{\text { radio, }}$, televisi, film, poster, dan spanduk; yang terletak di antara dua pihak (orang, golongan, dan sebagainya); perantara; penghubung. Massa adalah jumlah yang banyak sekali; sekumpulan orang yang banyak sekali. Masih menurut KBBI, media massa adalah "sarana dan saluran resmi 
sebagai

alat komunikasi untuk menyebarkan berita dan pesan kepada masyarakat luas".

Media adalah bentuk jamak dari medium yang berarti tengah atau perantara. Massa berasal dari bahasa Inggris yaitu mass yang berarti kelompok, kumpulan, atau orang banyak. Media massa memiliki peran penting di era yang serba modern. Salah satu peran penting media adalah sebagai penentu identitas suatu bangsa. Perkembangan yang terjadi dalam dunia media massa saat ini seperti perkembangan teknologi dunia elektronik, penggunaan internet secara luas dan penggunaan telepon seluler, yang secara tidak langsung memfasilitasi proses globalisasi dalam dunia jurnalistik. Dengan adanya internet, atau penggunaan telepon genggam yang juga memiliki fasilitas internet, segala sesuatu dari dunia luar begitu mudah masuk ke Indonesia.

Berdasarkan beberapa pendapat di atas, dapat disimpulkan bahwa media massa merupakanbentuk komunikasi dan rekreasi yang menjangkau masyarakat secara luas sehingga pesan informasi yang sama dapat diterima secara serentak dan sesaat. Media massa terdiri dari media cetak (surat kabar, brosur, baleho, buku, majalah, dan tabloid) dan media elektronik (radio, televisi, video, film, piringan hitam, kaset, CD/DVD). Media massa diidentifikasikan sebagai media sosialisasi yang berpengaruh pula terhadap perilaku masyarakat.

Dalam penelitian ini, peneliti mengambil surat kabar Harian Musi Banyuasin yang terbit di kota Sekayu. Sekayu adalah sebuah kecamatan yang menjadi ibukota Kabupaten Musi Banyuasin, Sumatera Selatan, Indonesia. Secara administratif, kecamatan Sekayu merupakan lokasi kota Sekayu yang berstatus sebagai Ibukota. Kecamatan Sekayu bercirikan wilayah perkotaan (urban area). Oleh karena itu, surat kabar Harian Musi Banyuasin yang merupakan salah satu media massa yang dapat berperan dalam mencerdaskan masyarakat. Hal inilah yang menjadi agenda terbesar media massa. Selanjutnya, media massa dapat menjadi penggerak aktivitas sosial masyarakat. Sebagai instrumen pemberi warta tentunya sebuah koran, misalnya, memiliki sebuah kekuatan persuasif tersendiri untuk mengajak masyarakat melakukan sesuatu.

\section{METODE PENELITIAN}

Penelitian ini menggunakan metode deskriptif kualitatif menurut Sedarmayanti (2011:200) penelitian kualitatif bersifat deskriptif, cenderung menggunakan analisis dengan pendekatan induktif, proses dan makna (perspektif subjek) lebih ditonjolkan. 
Metode penelitian deskriptif berusaha untuk memaparkan, menginterpretasikan, objek berdasarkan kenyataan yang ada secara jelas dan terperinci.

Metode yang dipilih untuk mengumpulkan data dengan cara mencatat (Sudaryanto, 2015:139). Data dikumpulkan dengan cara mencatat penggunaan bentuk-bentuk kebahasaan (kata, frasa, atau klausa, dan kalimat) yang mengandung eufemisme dan disfemisme di dalam surat kabar yang dipilih. Data dikumpulkan beserta konteks dasar. Konteks data sangat diperlukan untuk mengidentifikasi kejadian eufemisme dan disfemisme dan untuk mengklarifikasikan maknanya.

\section{PEMBAHASAN}

\section{Bentuk Eufemisme dan}

Disfemisme dalam Rubrik Berita "Kriminal" Surat Kabar Harian Musi Banyuasin

Berdasarkan analisis distribusi yang dilakukan, selain terdapat distribusi eufemisme yang memiliki persamaan dengan bentuk yang digantikannya juga terdapat distribusi eufemisme yang berbeda dengan bentuk yang digantikannya. Perbedaan tersebut disebabkan oleh cakupan makna (komponen makna termasuk intensitas makna), kemetaforikan (unsur metafora) dan kemampuan sebagai komplemen (pembubuhan bentuk negasi).
Chaer (2009:143) mengemukakan mengenai perubahan makna yang meluas, menyempit, atau berubah secara total, kita berhadapan dengan sebuah kata atau sebuah bentuk yang tetap. Hanya konsep makna mengenai kata atau bentuk itu yang berubah. Dalam hal penghalusan ini kita berhadapan dengan gejala ditampilkannya kata-kata atau bentuk-bentuk yang dianggap memiliki makna yang lebih halus atau lebih sopan daripada yang akan digantikan. Kecenderungan untuk menghaluskan makna kata tampaknya merupakan gejala umum dalam masyarakat.

Aspek cakupan makna memberikan pengaruh dalam distribusi eufemisme, karena dapat menentukan pola pendistribusian eufemisme dalam satu kalimat. Dalam contoh kata nyanyian bersinonim dengan kata ucapan, kedua kata itu berbeda karena kata nyanyian dianggap lebih mempunyai nilai rasa yang sopan didengar, halus, dan hormat. Hal yang sama dijumpai dalam cakupan makna kata pandang bulu yang lebih luas dibandingkan dengan cakupan makna tidak melihat siapa pun; intensitas makna kata seksi yang lebih tinggi daripada kata menggiurkan.

Berdasarkan analisis kolokasi, ditemukan kecenderungan pemakaian eufemisme di luar kolokasi yang sebenarnya. Kecenderungan itu dapat disebabkan oleh unsur metafora, pergeseran kolokasi, dan pergeseran 
makna, sehingga kelaziman itu hanya berlaku pada konteks tertentu.

Berdasarkan analisis distribusi yang dilakukan, selain terdapat distribusi disfemisme yang memiliki persamaan dengan bentuk yang digantikannya. Perbedaan tersebut disebabkan oleh cakupan makna (komponen makna termasuk intensitas makna), kemetaforikan (unsur metafora), dan kemampuan sebagai komplemen (pembubuhan bentuk negasi).

Sesuai dengan pendapat Chaer (2011:140) yang menyatakan bahwa disfemisme merupakan kebalikan dari eufemisme, yaitu usaha untuk mengganti kata yang maknanya halus atau bermakna biasa dengan kata yang bermakna kasar.

Makna menjijikkan ditemukan dalam kata kejam merupakan disfemisme dari kata jahat. Kedua bentuk ini secara gramatikal berdistribusi sama, yakni dapat dipakai untuk menerangkan keadaan dan perbedaannya kata kejam dianggap lebih kasar daripada kata jahat.

Makna menguatkan ditemukan dalam kata kabur merupakan disfemisme dari kata pergi. Kedua bentuk ini secara gramatikal berdistribusi sama, yakni dapat dipakai untuk menerangkan suatu pekerjaan, keadaan dalam bentuk aktivitas yaitu memegang sesuatu lalu dibawa.
Perbedaannya, kata kabur dianggap lebih kasar daripada kata pergi, karena kata kabur dapat bersifat negatif sedangkan mengambil bersifat positif. Hal yang sama juga terdapat dalam kata ditujah merupakan disfemisme dari kata ditikam, kedua bentuk ini secara gramatikal berdistribusi sama, yakni dapat dipakai untuk menerangkan keadaan yang terjadi. Perbedaannya, kata ditujah dianggap lebih kasar daripada kata ditikam. Hal yang sama katamendobrak merupakan disfemisme dari kata membobol, kedua bentuk ini secara gramatikal berdistribusi sama, yakni dapat dipakai untuk menerangkan keadaan dan perbedaannya kata mendobrak dianggap lebih kasar daripada kata membobol. Hal yang sama kata parah merupakan disfemisme dari kataserius, kedua bentuk ini secara gramatikal berdistribusi sama, yakni dapat dipakai untuk menerangkan keadaan dan perbedaannya kata parah dianggap lebih kasar daripada kata serius. Hal yang sama dalam kata maut merupakan disfemisme dari kata kematian, kedua bentuk ini secara gramatikal berdistribusi sama, yakni dapat dipakai untuk menerangkan keadaan dan perbedaannya kata maut dianggap lebih kasar daripada kata kematian. Hal yang sama dalam katakurungan merupakan disfemisme dari kata belenggu, kedua bentuk ini secara gramatikal berdistribusi sama, 
yakni dapat dipakai untuk menerangkan keadaan dan perbedaannya kata kurungan dianggap lebih kasar daripada kata belenggu.

Penggunaan bentuk disfemisme yang dominan dalam Harian Musi Banyuasin "Kriminal" mempengaruhi pola berpikir masyarakat sesuai pola pikir penulis yang ingin disampaikan. Tatkala penulis menggunakan bentuk disfemisme sebagai kritikan terhadap suatu permasalahan atas situasi pemerintahan dan politik yang terjadi, maka masyarakat secara tidak langsung

akan terbentuk pola pikir dan cara pandang sesuai apa yang ingin disampaikan oleh penulis. Sebagai akibatnya, masyarakat yang membaca akan terbuka matanya dan menjadi sadar, kritis terhadap situasi yang terjadi.

Selain mengubah pola pikir masyarakat, efek dari pemakaian disfemisme mampu membuat simpati masyarakat bahkan membuat sesuatu menjadi buruk di mata masyarakat. Disfemisme merupakan suatu pernyataan yang berfungsi menjadikan sesuatu terdengar lebih buruk atau lebih serius dari pada kenyataannya dan kebalikan dari eufemisme. Dengan kata lain, pemakaian disfemisme dapat menyebabkan suatu kata-kata atau ungkapan memiliki makna yang berbeda dari sesungguhnya.

Dalam kaitannya antara pemakaian bentuk disfemisme dengan pola berbahasa masyarakat, pemakaian bahasa yang kasar cenderung membuat pola berbahasa semakin kasar pula. Terdapat hubungan resiprokal antara berita yang diturunkan surat kabar dengan perubahan perilaku masyarakat.

Media massa digunakan dalam komunikasi apabila komunikasi berjumlah banyak dan bertempat tinggal jauh. Media massa yang banyak digunakan dalam kehidupan sehari-hari umumnya adalah surat kabar, radio, televisi, dan film bioskop, yang beroperasi dalam bidang informasi, edukasi dan rekreasi, atau dalam istilah lain penerangan, pendidikan, dan hiburan. Dalam surat kabar Harian Musi Banyuasin, masyarakat pembaca memiliki berbagai tipe pembaca seperti (1) tipe apresiatif dan baik hati, dalam tipe ini masyarakat pembaca tidak hanya membaca artikel seseorang saja tapi juga memberikan tanggapan yang positif, terlepas dari bagaimana kualitas tulisan tersebut; (2) tipe analitis, adalah pembacayang cenderung punya obyektivitas tinggi; (3) tipe biasa-biasa saja,tipe biasa-biasa saja ini sudah cukup puas hanya dengan membaca saja; dan (4) tipe anarkis sering muncul sebagai provokator dengan alasan memang ingin rusuh.

\section{KESIMPULAN DAN SARAN}

\section{Kesimpulan}


Berdasarkan hasil penelitian dan pembahasan eufemisme dan disfemisme dalam surat kabar Harian Musi Banyuasin periode Januari 2020 terhadap analisis komponen makna digunakan untuk meramalkan makna gramatikal, dapat juga kita lihat pada proses reduplikasi dan proses komposisi. Analisis komponen makna ini dapat dimanfaatkan untuk mencari perbedaan dari bentuk-bentuk bersinonim. Distribusi eufemisme dan disfemisme memiliki persamaan dengan bentuk yang digantikannya. Unsur metafora dapat menjadi penentu dalam distribusi disfemisme, karena dapat berpengaruh pada cakupan makna. Berdasarkan analisis kolokasi, ditemukan kecenderungan pemakaian eufemisme dan disfemisme yang disebabkan oleh pengeseran kolokasi sedangkan makna emotif suatu kata dapat menunjukkan nilai rasa terhadap makna yang dibawanya. Baik secara emosional maupun secara psikologis sehingga mampu melibatkan perasa. Makna emotif yang terdapat dalam analisis eufemisme dan disfemisme adalah makna menguatkan.

Makna emotif dapat dibedakan berdasarkan masyarakat yang menciptakannya atau menghasilkannya, dapat dibedakan berdasarkan media yang digunakan (lisan atau tulisan), serta menurut bidang yang menjadi isinya. Berdasarkan analisis distribusi, kolokasi, dan makna emotif dapat dikatakan tidak ada eufemisme dan disfemisme yang bersinonim secara absolut dan sempurna dengan bentuk kebahasaan yang digantikannya. Hal ini dipengaruhi oleh perbedaan distribusi, cakupan makna, pengesahan kolokasi, dan makna emotif.

Berdasarkan analisis komponen makna dan proses pembentukannya, bahasa digunakan untuk berbagai kegiatan dan keperluan dalam kehidupan bermasyarakat, maka makna bahasa itu pun menjadi bermacam-macam bila dilihat dari segi atau pandangan yang berbeda. Berbagai jenis makna telah dikemukakan orang dalam berbagai kalimat pada rubrik berita Harian Musi Banyuasin. Kiranya jenis-jenis makna yang dibicarakan pada berita sudah cukup mewakili jenis-jenis makna yang dibicarakan. Pemunculan pemakaian eufemisme dan disfemisme dalam surat kabar pada satu sisi dapat dianggap memperkaya khasanah bahasa Indonesia dan mampu menciptakan pergeseran makna. Akan tetapi, pada lain sisi hal ini juga dapat merusak pemakaian bahasa Indonesia, terutama dari sisi tata krama berbahasa yang santun, yang dapat membuat simbol semakin jauh dari referennya.

Penggunaan bentuk disfemisme mempengaruhi pola berpikir masyarakat. Tatkala penulis menggunakan bentuk disfemisme sebagai kritikan terhadap suatu 
permasalahan atas situasi pemerintahan dan politik yang terjadi, Berdasarkan analisis distribusi, kolokasi, dan makna emotif dapat dikatakan tidak ada eufemisme dan disfemisme yang bersinonim secara absolut dan sempurna dengan bentuk kebahasaan yang digantikannya. Hal ini dipengaruhi oleh perbedaan distribusi, cakupan makna, pengesahan kolokasi, dan makna emotif sehingga masyarakat secara tidak langsung akan terbentuk pola pikir dan cara pandang sesuai apa yang ingin disampaikan oleh penulis. Sebagai akibatnya, masyarakat yang membaca akan terbuka matanya dan menjadi sadar, kritis terhadap situasi yang terjadi.

\section{Saran}

Berdasarkan perkembangan pemakaian eufemisme dan disfemisme dalam surat kabar, setidaknya ada dua hal yang masih perlu dilakukan, yaitu sebagai berikut.

1. Dari segi kuantitas, penelitian tentang eufemisme dan disfemisme dalam surat kabar perlu dilakukan dengan skala yang lebih besar (skala nasional) dan dalam waktu yang cukup panjang, sehingga mampu menggambarkan pemakaian eufemisme dan disfemisme dalam surat kabar Indonesia secara menyeluruh.Selanjutnya, media massa dapat menjadi penggerak aktivitas sosial masyarakat. Sebagai instrumen pemberi warta tentunya sebuah koran, misalnya, memiliki sebuah kekuatan persuasif tersendiri untuk mengajak masyarakat melakukan sesuatu.

2. Dari sisi kualitas, perlu dilakukan penelitian yang lebih luas dan mendalam, terutama yang berkaitan dengan bidang linguistik terapan, misalnya pragmatik dan stilistika, mengingat penelitian yang dilakukan ini hanya berdasarkan kajian semantis dan sosiolinguistik.

\section{REFERENSI}

Anggraeni, Dian Wibi. 2016. Eufemisme dan Disfemisme dalam Talk Show Mata Najwa di Metro $T V$. Surabaya: Universitas Sebelas Maret.

Arikunto, Suharsimi. 2006. Prosedur Penelitian. Jakarta: Rineka Cipta.

Ariyani, Tutik. 2010. Analisis Penggunaan Disfemia pada Surat Kabar Meteor. Surakarta: Universitas Muhammadiyah Surakarta.

Chaer, Abdul. 2007. Linguistik Umum. Jakarta: Rineka Cipta.

Chaer, Abdul. 2009. Pengantar Semantik Bahasa Indonesia. Jakarta: Rineka Cipta.

Chaer, Abdul. 2010. Bahasa Jurnalistik. Jakarta: Rineka Cipta. 
Chaer, Abdul. 2011. Tata Bahasa Praktis Bahasa Indonesia. Jakarta: Rineka Cipta.

Djajasudarma, Fatimah. 2012. Semantik 1. Bandung: PT Refika Aditama.

Djajasudarma, Fatimah. 2016. Semantik 2. Bandung: PT Refika Aditama.

Emzir. 2007. Metodologi Penelitian Pendidikan Kuantitatif dan Kualitatif. Jakarta: PT Raja Grafindo Persada.

Emzir. 2015. Teori dan Pengajaran Sastra. Jakarta: PT Raja Grafindo Persada.

Faizah, Nur Farida Auzar Hasnah. 2015. Penggunaan Eufemisme dalam Tajuk Rencana Koran Kompas. Program Studi Pendidikan Bahasa dan Sastra Indonesia FKIP Universitas Riau.

Haryanta, Agung, Tri. 2012. Kamus Kebahasaan dan Kesastraan. Surakarta: Aksara Sinegi Media.

I Dewa Putu \& Muhammad Rohmadi, Wijana. 2008. Semantik, Teori dan Analisis. Surakarta: Yuma Pustaka.

Istiana, Rahayu Nur. 2006. Analisis Pemakaian Disfemia pada Rubrik Gagasan Surat Kabar Solopos. Surakarta. UNS-FKIP Jurusan Pendidikan Bahasa dan Seni.

Kosasih, E. 2003. Ketatabahasaan dan Kesusastraan. Bandung: Yrama Widya.

Masri, dkk. 2001. Kesinoniman Disfemisme dalam Surat Kabar Terbitan Palembang. Skripsi. Fakultas Keguruan dan Ilmu Pendidikan Universitas Muhammadiyah Surakarta.

Nasution, S. 2004. Metode Research. Jakarta: PT Bumi Aksara.
Panumbangan, Abraham. 2013. Majas Peribahasa Pembentukan Istilah Sinonim-Antonim. Yogyakarta: Buku Pintar.

Ratna, Kutha, Nyoman. 2013. Stilistika Kajian Puitika Bahasa, Sastra, dan Budaya. Yogyakarta: Pustaka Pelajar.

Riduwan. 2008. Metode dan Teknik Menyusun Tesis. Bandung: Alfabeta.

Sadikin, Mustofa. 2010. Kumpulan Sastra Indonesia. Jakarta: Gudang Ilmu.

Sedarmayanti, dkk. 2011. Metodologi Penelitian. Bandung: CV. Mandar Maju.

Suandi, I Nengah. 2014. Sosiolinguistik. Yogyakarta: Graha Ilmu.

Sudaryanto. 2014. Himpunan Lengkap Peribahasa Nusantara. Yogyakarta: Sketsa.

Sudaryanto. 2015. Metode dan Analisis Teknik Analisis Bahasa. Yogyakarta: Sanata Dharma University Press.

Sugiyono. 2009. Metode Penelitian Bisnis. Bandung: CV Alfabeta.

Suryabrata. 2014. Metodologi Penelitian. Jakarta: PT Raja Grafindo Persada.

Susanto, Dwi. 2016. Pengantar Kajian Sastra. Jakarta: CAPS

Tarigan, Henry Guntur. 2009. Pengajaran Pragmatik. Bandung: CV Angkasa.

Tarigan, Henry Guntur. 2011. Pengajaran Pemerolehan Bahasa. Bandung: CV Angkasa. 
Tarigan, Henry Guntur. 2013. Pengajaran Gaya Bahasa. Bandung: CV Angkasa.

Titscher, Stefan, dkk. 2000. Metode Analisis Teks dan Wacana. Yogyakarta: Pustaka Pelajar.

Ullman, Stephen. 2011. Pengantar Semantik. Yogyakarta: Pustaka Pelajar.
Waridah, Ernawati. 2014. Kumpulan Majas, Pantun, \& Peribahasa Plus Kesastraan Indonesia. Jakarta: Kawan Pustaka.

Wijana, I Dewa Putu, dan Muhammad Rohmadi. 2017. Semantik Teori dan Analisis. Surakarta: Yuma Pustaka.

Yudiono K.S, 2007. Pengantar Sejarah Sastra Indonesia. Jakarta: PT. Grasindo. 